\title{
PENERAPAN BUSINESS CONTINUITY MANAGEMENT PADA MASA PANDEMI COVID-19 DI PT BRANTAS ABIPRAYA
}

\author{
Wahyu Herry Sasongko ${ }^{1}$, Tatan Sukwika ${ }^{2}$ \\ ${ }^{1}$ Magister Manajemen, Sekolah Pascasarjana Universitas Sahid, Jakarta,wahyuherrys@gmail.com \\ ${ }^{2}$ Program Studi Teknik Lingkungan, Fakultas Teknik Universitas Sahid, Jakarta, tatan.swk@gmail.com
}

\begin{tabular}{ll|lll}
\hline Article history & \multicolumn{3}{l}{} \\
\hline Dikirim tanggal & $: 16 / 06 / 2021$ & Diterima tanggal & $:$ & $18 / 08 / 2021$ \\
Revisi pertama tanggal & $: 16 / 08 / 2021$ & Tersedia online tanggal & $:$ & $09 / 09 / 2021$ \\
\hline
\end{tabular}

\begin{abstract}
ABSTRAK
Abripraya telah menerapkan Business Continuity Management (BCM) sebagai upaya agar proses bisnis tetap berjalan dengan baik dalam kondisi risiko apapun, termasuk saat terjadi pandemi virus Covid19. Namun, di Abipraya, masih ada risiko bisnis yang perlu diselesaikan yaitu pelanggaran SOP terkait pencegahan Covid-19. Penelitian ini bertujuan untuk mengetahui kelompok risiko mana yang berisiko tinggi untuk menerapkan Business Continuity Management di Abipraya selama masa pandemi Covid-19. Metode pengumpulan data digunakan melalui observasi lapangan, dokumentasi kegiatan, dan wawancara yang berkaitan dengan objek dalam penelitian. Hasil penelitian menemukan enam risiko dengan level sangat tinggi, satu peluang dengan level tinggi, dan level sedang akibat pelanggaran implementasi BCM oleh pihak eksternal Abipraya. Pelanggaran pelaksanaan BCM mayoritas dilakukan oleh pekerja proyek periode tertentu seperti vendor dan subkontraktor, pengunjung yang berkunjung, dan pengemudi ojek online. Kesimpulannya, sekitar 75\% kelompok risiko dengan kategori risiko sangat tinggi untuk BCM Abipraya selama pandemi Covid-19. Implikasi manajerial adalah mensosialisasikan regulasi, terutama kepada pihak eksternal, dan mengimplementasikan rencana mitigasi secara berkala untuk mengurangi risiko tinggi.
\end{abstract}

Kata Kunci: Business Continuity Management, Covid-19, Risiko Bisnis, Abipraya

\begin{abstract}
ABSTACT
Abripraya has implemented Business Continuity Management (BCM) as an effort to keep business processes running well under any risk conditions, including when the Covid-19 virus pandemic occurs. However, in Abipraya, there are still business risks that need to be resolved, namely violations of SOPs related to preventing Covid-19. This study aims to determine which risk groups are at high risk for applying Business Continuity Management in Abipraya during the Covid-19 pandemic. Data collection methods are used through field observations, documentation of activities, and interviews related to the object in the study. The results found six risks with a very high level, one chance with a high level, and a medium level due to violations of BCM implementation by Abipraya's external parties. The majority of breaches of the implementation of BCM by period-specific project workers such as vendors and subcontractors, visiting visitors, and online motorcycle taxi drivers. In conclusion, about $75 \%$ of the risk group with a very highrisk category for the BCM Abipraya during the Covid-19 pandemic. The managerial implication is to disseminate regulations, especially to external parties, and implement periodic mitigation plans to reduce high risk.
\end{abstract}

Key Words: Business Continuity Management, Covid-19, Bussiness Risk, Abipraya 


\section{PENDAHULUAN}

PT Brantas Abipraya (Abipraya) merupakan salah satu Badan Usaha Milik Negara yang berdedikasi dalam menyediakan jasa konstruksi dan telah berperan aktif dalam mengembangkan dan mendukung tumbuh kembang di berbagai bidang. Pertama kali hadir di bidang infrastruktur 40 tahun lalu di dalam dan luar negeri, Abripraya terus bertransformasi untuk memperkuat daya saingnya. Pasca dimulai merebaknya Corona Virus Disease (Covid-19) yang berdampak pada pelambatan perekonomian global, termasuk perusahaan konstruksi seperti Abripraya. Perlambatan ekonomi ini bahkan mendorong adanya penerapan berbagai regulasi seperti bekerja dari rumah atau work from home (WFH) hingga kepengurangan jumlah tenaga kerja (Abipraya, 2020). Tidak hanya itu, kebijakan pemberlakuan pembatasan sosial skala berslaka besar (PSBB) telah berdampak secara signifikan khususnya pada para pelaku usaha yang kesulitan menjalankan usaha secara normal.

Pandemik Covid-19 ini berdampak besar pada kinerja dunia usaha terutama dibidang jasa, khususnya kontruksi. Dengan segala keterbasan, kontribusi sektor jasa konstruksi di bidang ekonomi masih dapat menyumbang cukup besar yaitu sebesar 11,26\% (Yuliana, 2020). Pasca dimulai merebaknya corona virus disease (Covid-19) yang berdampak pada perekonomian global, termasuk perusahaan konstruksi seperti Abripraya. Perlambatan ekonomi yang dimulai pada awal Maret 2020 akibat penerapan berbagai regulasi seperti bekerja dari rumah (WFH) hingga ke pengurangan jumlah karyawan (Abipraya, 2020). Pemerintah telah mengeluarkan berbagai kebijakan mulai dari pelonggaran impor alat kesehatan hingga memutuskan pemberlakuan pembatasan sosial skala berslaka besar (PSBB). Sehingga fenomena ini melanda para pelaku usaha terutama dibidang jasa, khususnya kontruksi. Dengan segala keterbasan, kontribusi sektor jasa konstruksi di bidang ekonomi masih dapat menyumbang cukup besar yaitu sebesar 11,26\% (Yuliana, 2020). Abripraya sebagai perusahaan konstruksi juga telah merasakan dampak dari krisis pandemi Covid-19 seperti penurunan dibandingkan tahun sebelumnya, kontrak mengalami penurunan nilai akibat pemotongan anggaran, penyelesaian proyek tertunda, mobilisasi dan ketersediaan tenaga kerja, bahan dan peralatan terhambat oleh aplikasi. Dampak Covid-19 ini pun telah berdapka pada kenaikan biaya produksi juga menjadi faktor penyebab turunnya kinerja bisnis. Tenaga kerja yang sebagian besar terampil dan didatangkan dari luar daerah tidak dapat bekerja secara maksimal karena keterlambatan material sedangkan upah produksi belum dibayar. Selain itu, perusahaan dituntut melakukan perubahan atau redistribusi anggaran terhadap Covid-19 agar dampak pandemi ini tidak menyebar luas di lingkungan tempat kerja.

Dampak Covid-19 berpengaruh pada terhambatnya proses kegiatan bisnis perusahaan konvensional yang memerlukan interaksi antar karyawannya sehingga kegiatan operasional perusahaan (Yuliana, 2020). Hal ini mendorong perusahaan untuk memikirkan strategi dalam menghadapi situasi pandemi sehingga diperlukan standar keamanan yang tinggi dengan cara mengimplementasikan mengenai manajemen keberlangsungan bisnis atau yang biasa disebut Business Continuity Management (BCM) untuk menghadapi bahaya ketidakpastian ekonomi domestic dan ekonomi global (Baba, 2014; de Castro Alves \& de Almeida, 2015). Implementasi BCM dalam perusahaan di masa pandemic ini menjadi suatu langkah penting karena bertujuan agar perusahaan memiliki ketahanan pada bidang operasional bisnis dan keandalan dan keamanan dalam proses bisnis perusahaan (de Castro Alves \& de Almeida, 2015). Sehingga bila terjadi suatu bencana ataupun gangguan proses operasional, maka bisnis tetap dapat berjalan 
sesuai yang telah direncanakan sebelumnya (Baba, 2014; Harmoko, 2014; Hikmah \& Sukwika, 2021; Setiawan et al., 2019).

BCM telah menjadi standar internasional yaitu ISO 22301 yang menjadi dasar perancangan $\mathrm{BCM}$ untuk mengatur pengelolaan kelangsungan bisnis, proses bisnis, dan kelangsungan bisnis. BCM direncanakan untuk mengidentifikasi risiko yang muncul dan mengantisipasi risiko yang akan merugikan perusahaan. Penyelidikan bencana nasional Covid-19 saat ini terkait dengan kelangsungan bisnis perseroan terkait hasil asesmen dan strategi yang diterapkan Abripraya. Dengan menerapkan BCM yang terkait dengan ISO 22301, para pemangku kepentingan (stakeholders) dapat mempercayai bahwa perusahaan dapat menjalankan proses bisnisnya sedemikian rupa sehingga proses bisnis tidak terganggu (Amanda, 2014; Prakasita \& Ginardi, 2018; Zainudin \& Samopa, 2017). Penelitian ini bertujuan menentukan faktor-faktor penting yang berisiko terhadap penerapan Business Continuity Management Abipraya pada masa pandemi Covid-19.

\section{KAJIAN PUSTAKA}

Business Continuity Management (BCM) adalah suatu proses yang harus ada di perusahaan karena memiliki tujuan untuk perusahaan atau organisasi memiliki langkah mitigasi untuk bencana ataupun gangguan yang akan terjadi dan berpotensi mengganggu jalannya operasional (Baba, 2014; de Castro Alves \& de Almeida, 2015; Harmoko, 2014; Hikmah \& Sukwika, 2021). BCM dirancang supaya perusahaan atau organisasi tetap dapat menjalankan unit bisnisnya secara efektif dengan tanpa mengurangi kinerjanya. Untuk dapat memiliki BCM yang bagus, perusahaan perlu melakukan back testing terhadap BCM yang telah disusun dengan cara mensimulasikan ancaman-ancaman yang ada dan melakukan improvisasi dan revisi terhadap BCM yang sudah ada. BCM akan efektif apabila para stakeholder memiliki komitmen yang tinggi serta kesadaran akan pentingnya penerapan BCM diluar dari berapa biaya yang diperlukan untuk dapat menyusun dan mengimplementasikan BCM tersebut.

Business Continuity Plan (BCP) merupakan sebuah rencana atau strategi untuk membuat sistem pencegahan untuk meminimalisir kerugian yang dapat terjadi dengan adanya hal-hal yang bersifat tak terduga (uncertainty) (Svata, 2013). Pengaplikasian BCP difokuskan kepada sumber daya manusia yang dituntut untuk bersifat agile sehingga dapat dengan mudah beradaptasi dan mengaplikasikan lagkah mitigasi yang telah disusun sebelumnya (Burtles, 2016). Macam-macam bencana yang umumnya dimasukkan ke dalam BCP seperti bencana alam gempa dan banjir dan wabah penyakit (Harmoko, 2014). Sedangkan dari sisi ekonomi adalah adanya krisis moneter, inflasi, dan keadaan pasar yang tidak menentu (Baba, 2014; de Castro Alves \& de Almeida, 2015).

Business Continuity Plan (BCP) memiliki tujuan untuk mengusahakan agar dapat menekan risiko kerugian seminimal mungkin. Selain itu BCP juga bertujuan agar perusahaan atau organisasi memiliki proses pemulihan secepat mungkin agar risiko kerugian tidak terlalu besar. Yang perlu ditekankan disini adalah BCP bukan merupakan tools untuk menghindari risiko melainkan untuk meminimalisir dampaknya. Saat membuat $\mathrm{BCP}$, maka faktor yang harus mempertimbangkan sejauh mana kemungkinan terkena dampak krisis antara lain sumber daya manusia, proses bisnis perusahaan atau organisasi, lokasi untuk melakukan proses bisnis, teknologi pengaplikasian $\mathrm{BCP}$, dan rencana keberlangsungan usaha (Burtles, 2016; Ramli, 2020).

Standar ISO 22301 berisi tentang perencanaan bagaimana mengatasi suatu 
bencana atau lebih dikenal dengan mitigasi yang bertujuan untuk meminimalisir kerugian yang diakibatkan oleh ketidakpastian keadaan. Dengan adanya perencanaan tindakan preventif, diharapkan mampu menahan efek domino yang akan terjadi ketika perusahaan atau organisaasi tersebut dihadapkan dengan suatu bencana baik bencana fisik maupun bencana non fisik seperti bencana ekonomi dan politik. Standar dari ISO 22301 mengedepankan kontinuitas bisnis dimana dalam hal ini menuntut komitmen dari pimpinan perusahaan karena dalam menyusun dan mengimplemntasikan pedomanpedoman yang ada di dalamnya diperlukan biaya. Standar ISO 22301 juga menggunakan pola PDCA (plan-do-check-act) dalam proses pengaplikasiannya yang bertujuan supaya apa yang sudah dirumuskan sebelumnya bisa terus update dengan kondisi aktual yang sedang terjadi pada perusahaan atau organisasi (Amanda, 2014; Prakasita \& Ginardi, 2018; Putri, 2016; Zainudin \& Samopa, 2017). Mengacu pada standar ISO 22301, penyusunan Business Continuity Plan memiliki beberapa tahapan dimulai dari tahapan menerapkan kebijakan, mengidentifikasi risiko-risiko apa saja yang mengkin dihadapi, menetapkan struktur organisasi dilengkapi dengan tugas dan tanggung jawab masingmasing personil, menentukan mekanisme pekerjaan dan prosedur operasional serta upaya untuk pemulihan yang harus dilakukan ketika bahaya risiko benar-benar terjadi (Ramli, 2020; Waatters, 2010).

\section{METODE PENELITIAN}

Lokasi penelitian adalah kantor pusat Abripraya di Jakarta. Penelitian ini dilakukan selama dua bulan mulai November hingga Desember 2020. Pengumpulan data dilakukan melalui cara observasi langsung di lapangan, dokumentasi kegiatan, dan melakukan wawancara serta brainstorming mengenai hal-hal yang berkaitan dengan objek pada penelitian (Sugiyono, 2017). Beberapa tahapan pengumpulan data dalam penelitian ini meliputi penelitian kepustakaan, observasi, dan dokumentasi. Fase terakhir berlangsung melalui wawancara. Wawancara dilakukan dengan direktur unit. Perusahaan sebagai pembuat kebijakan, pengawas lapangan sebagai pelaksana kebijakan dan pegawai di lingkungan proyek PT Brantas Abipraya (Persero) yang diharapkan dapat memberikan bantuan selain pendataan yang dibutuhkan. Proses wawancara dilakukan secara individu baik secara tatap muka atau virtual untuk mendukung penerapan physical distancing pada saat pandemi Covid-19.

Studi literatur dilakukan pada dokumen perusahaan terkait kegiatan Business Continuity Management (BCM). Dokumen tersebut berupa manual perusahaan, prosedur operasi, standar perusahaan (SOP), pedoman perusahaan, dan pedoman perusahaan. Peraturan perusahaan yang harus dipatuhi dan ditaati di perusahaan. Pada tahap ini dilakukan observasi untuk memperoleh rekaman atau foto pelanggaran yang terjadi sesuai dokumen yang diperiksa. Dilakukan juga wawancara terhadap pihak-pihak yang menjadi bagian dari implementasi BCM. Saat wawancara dieksplorasi alasan-alasan pelaku pelanggaran tidak melaksanakan peraturan-peraturan yang diberlakukan. Informasi hasil wawancara dijadian acuan rancangan penyempurnaan untuk mendukung implementasi BCM di Abipraya.

\section{Metode Analisis Data}

Berdasarkan informasi proses bisnis yang dilakukan oleh Abripraya serta analisis ancaman yang telah ditentukan maka perlu dilakukan dua analisis terpisah yaitu analisis dampak bisnis akibat tidak dilaksanakannya prosedur Business Continuity Management 
(BCM) dan analisis risiko. Dalam melakukan analisis dampak bisnis di PT Brantas Abipraya (Persero), penulis menggunakan tools berupa dokumen rujukan yaitu ISO 22301. Dalam ISO 22301, teknik yang digunakan adalah plan, do, check, act (PDCA). Semetara, Analisis risiko dilakukan kepada risiko-risiko yang telah diidentifikasi sebelumnya untuk mengetahui seberapa besar risiko tersebut dapat berdampak kepada aktivitas bisnis perusahaan. Penilaian besarnya risiko menggunakan metode failure mode and effect analysis dengan cara melakukan perhitungan nilai dampak (severity), nilai kemungkinan (occurence) dan nilai deteksi (detection). Risiko-risiko tersebut selanjutnya dinilai dengan metode FMEA (failure mode effect analysis) dengan mengkalikan nilai severity number, occurence number, dan detection number yang nantinya akan menghasilkan risk probability number (RPN). Penilaian level risiko mengacu pada persamaan FMEA yang berfungsi mengetahui seberapa besar suatu identifikasi risiko memiliki nilai risiko dapat berpengaruh pada jalannya proses bisnis perusahaan, persamaan penilaiannya sebagai berikut.

\section{RPN = Severity $x$ Occurence $x$ Detection}

Dari hasil RPN, maka dapat diketahui tingkat risiko tersebut secara terukur dengan metode kuantitatif sehingga memudahkan dalam mengukur berapa besarnya risiko. Risiko yang dapat diterima adalah apabila memiliki risiko medium, sehingga apabila ditemukan nilai identifikasi risiko di atas nilai medium harus dilakukan mitigasi untuk menentukan nilai risikonya (Fajriansah, 2017). Skala nilai level risiko dapat dilihat pada Tabel 1.

Tabel 1.

Skala Level Risiko RPN

\begin{tabular}{cc}
\hline Level Risiko & Skala Nilai RPN \\
\hline Very High & $>200$ \\
High & $121-200$ \\
Medium & $81-120$ \\
Low & $21-80$ \\
Very Low & $<20$ \\
\hline
\end{tabular}

\section{HASIL DAN PEMBAHASAN}

\section{Identifikasi Risiko}

Setelah melakukan pengumpulan data melalui metode studi kepustakaan, diperoleh beberapa identifikasi masalah didasarkan pada hasil observasi dokumen SOP Abipraya. SOP tersebut dijadikan dokumen rujukan tentang apa yang harus dilakukan perusahaan terkait dengan BCM dalam rangka menghadapi penyebaran virus Covid-19.

Identifikasi masalah tersebut mencakup hal-hal apa saja yang sudah dilaksanakan dan hal-hal apa saja yang belum dilakukan serta hal-hal yang sudah dilakukan tetapi masih terjadi pelanggaran didalamnya. Pembuatan checklist berdasarkan dokumen SOP Pedoman pelaksanaan New Normal No dokumen 2-000-57-14/01. Adapun identifikasi masalah yang berhasil ditemukan selama proses identifikasi risiko sebagai berikut: (1) Penerapan perilaku hidup bersih dan disiplin menjalankan protokol pencegahan penularan virus Covid-19 di lokasi proyek; (2) Pemeriksaan kesehatan secara berkala di lokasi proyek; (3) Kapasitas mess atau barak di lokasi proyek tidak sesuai dengan jumlah pekerja; (4) Pelanggaran jaga jarak di ruang tunggu sopir dan ojek sesuai ketentuan pencegahan penyebaran virus Covid-19; (5) Pelanggaran jaga jarak di ruang tunggu 
tamu/customer/loby sesuai ketentuan pencegahan penyebaran virus Covid-19; (6) Pelanggaran jaga jarak saat naik lift sesuai ketentuan pencegahan penyebaran virus Covid-19; (7) Tidak semua tamu memiliki surat keterangan bebas Covid-19 terutama tamu dari dalam kota; (8) Tamu hanya menggunakan APD berupa masker.

\section{Penilaian Risiko}

Berdasarkan identifikasi risiko yang sudah ditentukan dan dikelompokkan sesuai klausul pada dokumen ISO 22301. Terdapat 6 risiko yang mempunyai level risiko very high, 1 risiko dengan level high, dan 1 risiko dengan level medium. Hasil nilai risiko pada masing-masing identifikasi risiko disajikan pada Tabel 2.

Selanjutnya penyusunan rencana mitigasi untuk identifikasi risiko pada nomor 1 sampai dengan nomor 7 disajikan pada Tabel 3. Untuk langkah mitigasi hanya diterapkan pada level risiko high dan very high. Sedangkan untuk identifikasi risiko nomor 8 tidak perlu dilakukan mitigasi karena memiliki nilai risiko yang masih dapat diterima.

Tabel 2.

Nilai Risiko Pada Masing-Masing Identifikasi Risiko

\begin{tabular}{clcc}
\hline No. & Identifikasi Risiko & Nilai Risiko & Level Risiko \\
\hline 1 & $\begin{array}{l}\text { Penerapan perilaku hidup bersih dan disiplin menjalankan protokol } \\
\text { pencegahan penularan virus Covid-19 di lokasi proyek. }\end{array}$ & 240 & Very High \\
\hline 2 & $\begin{array}{l}\text { Pemeriksaan kesehatan secara berkala di lokasi proyek. } \\
\text { pekerja. }\end{array}$ & 210 & Very High \\
\hline 3 & $\begin{array}{l}\text { Kapasitas mess atau barak di lokasi proyek tidak sesuai dengan jumlah } \\
\text { Very High }\end{array}$ & Very High \\
\hline 4 & $\begin{array}{l}\text { Pelanggaran jaga jarak di ruang tunggu sopir dan ojek sesuai ketentuan } \\
\text { pencegahan penyebaran virus Covid-19. }\end{array}$ & 210 & Very High \\
\hline 5 & $\begin{array}{l}\text { Pelanggaran jaga jarak di ruang tunggu tamu/customer/ loby sesuai } \\
\text { ketentuan pencegahan penyebaran virus Covid-19. }\end{array}$ & 210 & Very High \\
\hline 6 & $\begin{array}{l}\text { Pelanggaran jaga jarak saat naik lift sesuai ketentuan pencegahan } \\
\text { penyebaran virus Covid-19. }\end{array}$ & 280 & High \\
\hline 7 & $\begin{array}{l}\text { Tidak semua tamu memiliki surat keterangan bebas Covid-19 terutama } \\
\text { tamu dari dalam kota. }\end{array}$ & 96 & Medium \\
\hline 8 & Tamu hanya menggunakan APD berupa masker. & & Ho \\
\hline
\end{tabular}

\section{Penurunan Nilai Risiko}

Penurunan nilai risiko masing-masing identifikasi risiko diperoleh setelah melakukan wawancara dan mendapatkan rencana mitigasi pada masing-masing risiko. Mitigasi yang dipilih yang dapat menurunkan nilai risiko terbanyak yaitu: (1) Memberikan reward bagi yang melakukan penerapan protokol dan punishment bagi pelanggar protocol; (2) Menambah jumlah tenaga medis; (3) Memberi sekat tiap ruangan untuk mencegah penularan virus Covid-19; (4) Menerapkan antrian untuk sopir atau ojek online untuk berada di ruang tunggu; (5) Melakukan reservasi untuk menentukan jadwal kunjungan; (6) Memasang sticker tentang peraturan saat naik lift; (6) Melakukan self assessment khusus tamu pada aplikasi Ayo Sehat Brantas Abipraya.

Pada Tabel 3 diketahui mayoritas pelanggar protokol pencegahan penularan virus Covid-19 di area kantor pusat maupun area proyek Abipraya dilakukan oleh pihak eksternal yaitu para pekerja proyek yang dipekerjakan pada periode proyek tertentu dan juga para tamu yang berkunjung termasuk sopir ojek online. Informasi penyebab timbulnya pelanggaran tersebut diperoleh dari hasil wawancara kepada pelanggar protokol pencegahan penularan virus Covid-19. Informasi tersebut menjadi data untuk digunakan sebagai dasar penyusunan rencana mitigasi. Pada Tabel 3 diketahui tingkat 
penurunan nilai risiko untuk masing-masing identifikasi risiko didasarkan pada rencana mitigasi yang akan dilakukan. Rencana mitigasi yang akan dipilih adalah rencana mitigasi yang mampu menurunkan nilai risiko terbesar tanpa memperhitungkan aspek biaya yang dikeluarkan untuk mengaplikasikan mitigasi tersebut.

Tabel 3.

Penyebab Risiko untuk Masing-Masing Identifikasi Risiko

\begin{tabular}{|c|c|c|}
\hline No & IDENTIFIKASI RISIKO & PENYEBAB \\
\hline 1 & $\begin{array}{l}\text { Penerapan perilaku hidup } \\
\text { bersih dan disiplin menjalankan } \\
\text { protokol pencegahan penularan } \\
\text { virus Covid-19 di lokasi proyek. }\end{array}$ & $\begin{array}{l}\text { Mayoritas pekerja proyek merupakan pekerja dengan tingkat } \\
\text { pendidikan yang rendah sehingga tidak memiliki literasi tentang } \\
\text { pentingnya menjaga kebersihan dan menjalankan protokol } \\
\text { pencegahan penularan virus Covid-19 di lokasi proyek. }\end{array}$ \\
\hline 2 & $\begin{array}{c}\text { Pemeriksaan kesehatan } \\
\text { secara berkala di lokasi proyek. }\end{array}$ & $\begin{array}{l}\text { Jumlah tenaga kesehatan tidak sebanding dengan jumlah } \\
\text { pekerja di proyek sehingga tenaga kesehatan tidak memiliki cukup } \\
\text { waktu untuk memeriksa semua pekerja yang ada. }\end{array}$ \\
\hline 3 & $\begin{array}{l}\text { Kapasitas mess atau barak } \\
\text { di lokasi proyek tidak sesuai } \\
\text { dengan jumlah pekerja. }\end{array}$ & $\begin{array}{l}\text { Kapasitas mess atau barak didesain berdasarkan jumlah } \\
\text { pekerja pada masa sebelum pandemi Covid-19, sehingga dengan } \\
\text { adanya peraturan jaga jarak, mengakibatkan mess atau barak tidak } \\
\text { dapat mengakomodir jumlah pekerja apabila ditetapkan peraturan } \\
50 \% \text { kapasitas. }\end{array}$ \\
\hline 4 & $\begin{array}{l}\text { Pelanggaran jaga jarak di } \\
\text { ruang tunggu sopir dan ojek } \\
\text { sesuai ketentuan pencegahan } \\
\text { penyebaran virus Covid-19. }\end{array}$ & $\begin{array}{l}\text { Jumlah kapasitas ruang tunggu untuk sopir dan ojek online } \\
\text { yang mengharuskan kapasitas maksimum hanya } 50 \% \text { dari } \\
\text { kapasitas normal menyebabkan ruang tunggu menjadi overload } \\
\text { dan tidak dapat menjalankan protokol pencegahan penularan virus } \\
\text { Covid-19. }\end{array}$ \\
\hline 5 & $\begin{array}{l}\text { Pelanggaran jaga jarak di } \\
\text { ruang tunggu tamu/ customer/ } \\
\text { loby sesuai ketentuan } \\
\text { pencegahan penyebaran virus } \\
\text { Covid-19. }\end{array}$ & $\begin{array}{l}\text { Jumlah kapasitas ruang tunggu untuk tamu/customer/loby } \\
\text { yang mengharuskan kapasitas maksimum hanya } 50 \% \text { dari } \\
\text { kapasitas normal menyebabkan ruang tunggu menjadi overload } \\
\text { dan tidak dapat menjalankan protokol pencegahan penularan virus } \\
\text { Covid-19. }\end{array}$ \\
\hline 6 & $\begin{array}{l}\text { Pelanggaran jaga jarak saat } \\
\text { naik lift sesuai ketentuan } \\
\text { pencegahan penyebaran virus } \\
\text { Covid-19. }\end{array}$ & $\begin{array}{l}\text { Pelanggaran kapasitas lift kebanyakan terjadi saat rushhour } \\
\text { seperti saat jam masuk kerja, jam istirahat, dan jam pulang kerja } \\
\text { karena penumpukan aktivitas di jam yang sama. }\end{array}$ \\
\hline 7 & $\begin{array}{l}\text { Tidak semua tamu } \\
\text { memiliki surat keterangan } \\
\text { bebas Covid-19 terutama tamu } \\
\text { dari dalam kota. }\end{array}$ & $\begin{array}{l}\text { Peraturan dari pemerintah pusat maupun pemerintah daerah } \\
\text { mengenai peraturan tentang bepergian hanya mengharuskan surat } \\
\text { keterangan bebas Covid-19 untuk orang yang bepergian antar kota. }\end{array}$ \\
\hline
\end{tabular}

Dari Tabel 4 diketahui rencana mitigasi apa yang dipilih dan berapa nilai risiko akhir yang didapatkan. Nilai akhir risiko yang diperoleh harus memiliki nilai risiko yang dapat diterima, yaitu nilai risiko dengan katagori medium. Setelah mengetahui langkah mitigasi apa yang harus diambil untuk menurunkan nilai risiko, maka tahap selanjutnya adalah implementasi dari rencana mitigasi yang telah ditentukan sebelumnya untuk memastikan proses bisnis perusahaan tetap dapat berjalan dengan baik di tengah pandemi Covid-19. Penelitian Verma dan Gustafsson (2020) mendeteksi pengaruh pandemi Covid-19 terhadap berbagai macam sector bisnis. Mekanisme pembatasan interaksi melalui protokol kesehatan yang diterapkan secara efektif oleh perusahaan dan mendapatkan respon baik dari stakeholder sangat menentukan penurunan nilai risiko. Kencenderungan ini telah dibuktikan juga oleh Zainudin dan Samopa (2017). 
Tabel 4.

Rencana Mitigasi yang Dipilih untuk Masing-Masing Identifikasi Risiko

\begin{tabular}{|c|c|c|c|}
\hline No & IDENTIFIKASI RISIKO & RENCANA MITIGASI & $\begin{array}{c}\text { NILAI } \\
\text { AKHIR RISIKO }\end{array}$ \\
\hline 1 & $\begin{array}{l}\text { Penerapan perilaku hidup bersih } \\
\text { dan disiplin menjalankan protokol } \\
\text { pencegahan penularan virus Covid-19 } \\
\text { di lokasi proyek. }\end{array}$ & $\begin{array}{l}\text { Memberikan reward bagi yang } \\
\text { melakukan penerapan protokol dan } \\
\text { punishment bagi pelanggar protokol. }\end{array}$ & $\begin{array}{c}108 \\
\text { (Medium) }\end{array}$ \\
\hline 2 & $\begin{array}{l}\text { Pemeriksaan kesehatan secara } \\
\text { berkala di lokasi proyek. }\end{array}$ & Menambah jumlah tenaga medis. & $\begin{array}{c}30 \\
(\mathrm{Low})\end{array}$ \\
\hline 3 & $\begin{array}{l}\text { Kapasitas mess atau barak di lokasi } \\
\text { proyek tidak sesuai dengan jumlah } \\
\text { pekerja. }\end{array}$ & $\begin{array}{l}\text { Memberi sekat tiap ruangan } \\
\text { untuk mencegah penularan virus } \\
\text { Covid-19. }\end{array}$ & $\begin{array}{c}60 \\
(\mathrm{Low})\end{array}$ \\
\hline 4 & $\begin{array}{l}\text { Pelanggaran jaga jarak di ruang } \\
\text { tunggu sopir dan ojek sesuai ketentuan } \\
\text { pencegahan penyebaran virus Covid-19. }\end{array}$ & $\begin{array}{l}\text { Menerapkan antrian untuk sopir } \\
\text { atau ojek online untuk berada di ruang } \\
\text { tunggu. }\end{array}$ & $\begin{array}{c}96 \\
\text { (Medium) }\end{array}$ \\
\hline 5 & $\begin{array}{l}\text { Pelanggaran jaga jarak di ruang } \\
\text { tunggu tamu/customer/ loby sesuai } \\
\text { ketentuan pencegahan penyebaran virus } \\
\text { Covid-19. }\end{array}$ & $\begin{array}{l}\text { Melakukan reservasi } \\
\text { menentukan jadwal kunjungan. }\end{array}$ & $\begin{array}{c}80 \\
(\mathrm{Low})\end{array}$ \\
\hline 6 & $\begin{array}{l}\text { Pelanggaran jaga jarak saat naik lift } \\
\text { sesuai ketentuan pencegahan } \\
\text { penyebaran virus Covid-19. }\end{array}$ & $\begin{array}{l}\text { Memasang sticker tentang } \\
\text { peraturan saat naik lift. }\end{array}$ & $\begin{array}{c}60 \\
(\mathrm{Low})\end{array}$ \\
\hline 7 & $\begin{array}{l}\text { Tidak semua tamu memiliki surat } \\
\text { keterangan bebas Covid-19 terutama } \\
\text { tamu dari dalam kota. }\end{array}$ & $\begin{array}{l}\text { Melakukan self assessment } \\
\text { khusus tamu pada aplikasi Ayo Sehat } \\
\text { Brantas Abipraya. }\end{array}$ & $\begin{array}{c}90 \\
\text { (Medium) }\end{array}$ \\
\hline
\end{tabular}

\section{Implementasi Rencana Mitigasi}

Implementasi rencana mitigasi pada masing-masing identifikasi risiko diharapkan mampu menjaga proses bisnis perusahaan dari ancaman pandemi virus Covid-19. Dengan adanya rencana mitigasi diharapkan mampu membawa perubahan terhadap kondisi saat ini di lapangan sehingga nilai risiko terhadap keberlangsungan proses bisnis perusahaan pada saat terjadi pandemi virus Covid-19 ini memiliki nilai risiko yang dapat diterima. Implementasi yang dilakukan untuk masing-masing identifikasi sebagai berikut:

\section{Penerapan perilaku hidup bersih dan disiplin menjalankan protokol pencegahan penularan virus Covid-19 di lokasi proyek.}

Dari hasil observasi sebelumnya diketahui bahwa kebersihan tidak terjaga di lokasi proyek. Banyak sisa material atau sampah yang tergeletak di lingkungan proyek akibat tidak langsung dibersihkan setelah aktivitas selesai. Kondisi itu terjadi karena mayoritas kesadaran dan kepedulian pekerja proyek masih rendah khususnya pada masa pandemi virus Covid-19. Berdasarkan hasil analisis risiko dan perhitungan nilai risiko, diketahui bahwa langkah mitigasi yang sesuai untuk identifikasi risiko ini adalah memberikan reward bagi yang melakukan penerapan protokol dan punishment bagi pelanggar protokol kesehatan. Mitigasi ini dinilai paling sesuai dengan kondisi di lapangan dimana para pelanggar kebijakan yang mayoritas pekerja dengan tingkat kedisiplinan yang rendah akan lebih patuh bila penegakan aturan menggunakan sistem reward dan punishment. Penerapan sistem yang terukur dan berkeadilan lebih efektif dalam menurunkan risiko 
dan meningkatkan kedisiplinan (Kartikasari \& Sukwika, 2021). Bahkan mendapatkan dukungan perbaikan dan peningkakan dari sistem tersebut (Kartikasari \& Sukwika, 2021; Prakasita \& Ginardi, 2018; Zainudin \& Samopa, 2017). Dari Gambar 1, diketahui bahwa langkah mitigasi yang diambil mampu secara efektif memberikan perubahan terhadap kondisi kebersihan lokasi proyek dan menurunkan nilai risiko terhadap proses bisnis Abipraya dimasa pandemi virus Covid-19.

\section{Gambar 1.}

Kondisi di lokasi proyek

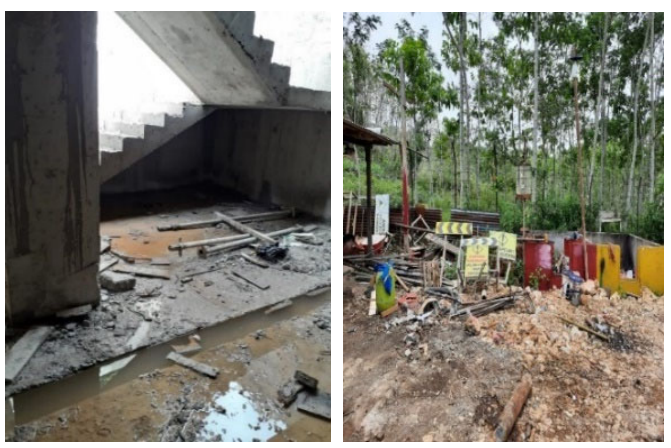

A: sebelum implementasi mitigasi
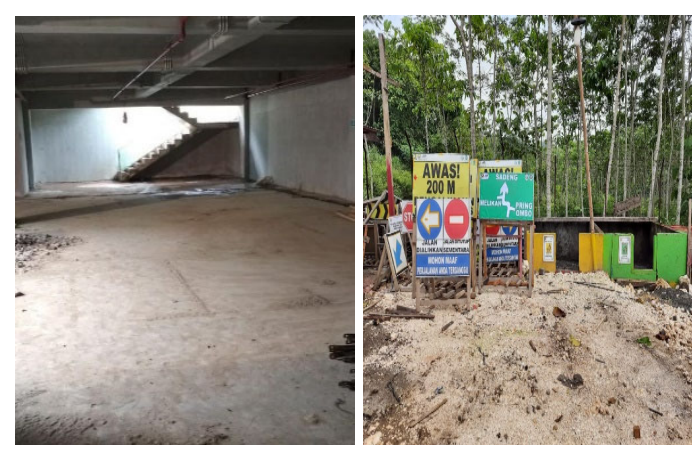

B: setelah implementasi mitigasi

\section{Pemeriksaan kesehatan secara berkala di lokasi proyek.}

Permasalahan yang dihadapi pada masa pandemi seperti yang terjadi di tahun 2020 ini adalah masalah kesehatan para pekerja di proyek. Selama ini tenaga medis diperuntukkan hanya menangani pekerja yang mengalami sakit dan kecelakaan kerja, sementara pada masa pandemi virus Covid-19 harus memeriksa kesehatan seluruh pekerja baik yang memiliki gejala penyakit yang terindikasi tertular virus Covid-19 maupun pekerja yang tanpa gejala. Untuk identifikasi risiko ini, dipilih alternaltif mitigasi berupa penambahan jumlah tenaga medis agar tenaga medis dapat memeriksa seluruh pekerja proyek sebelum mereka memasuki area proyek tanpa mengganggu jadwal kerja di lapangan. Proses pemeriksaan kesehatan secara rutin bagi pekerja di lokasi proyek dapat dilihat pada Gambar 2.

\section{Kapasitas mess atau barak di lokasi proyek tidak sesuai dengan jumlah pekerja.}

Kapasitas mess atau barak bagi pekerja dibuat berdasarkan perhitungan berapa jumlah pekerja yang akan dipakai untuk menyelesaikan sebuah proyek. Proyek yang sedang dikerjakan oleh Abipraya) merupakan proyek yang diperoleh dan diperhitungkan sebelum terjadinya pandemi virus Covid-19 sehingga tidak memperhitungkan kapasitas mess atau barak pekerja sesuai dengan peraturan mengenai penyebaran virus Covid-19. Untuk mencegah dan meningkatkan penyelamatan makan diperlukan system proteksi aktif (Sari \& Sukwika, 2020), khususnya bagi karyawan. Langkah mitigasi yang diambil berikutnya terkait kapasitas dari mess atau barak pekerja adalah dengan memasang sekat dan membatasi kapasitas tempat tidur. Untuk membatasi kapasitas mess atau barak dilakukan dengan pemberian sekat pada tempat tidur sehingga tempat tidur yang biasanya digunakan oleh dua orang menjadi hanya bisa digunakan oleh satu orang. Sebagai gantinya, dilakukan pengalihan pemanfaatan ruangan lain menjadi ruang untuk tempat 
tidur untuk tetap dapat menjalankan Prosedur Pelaksanaan New Normal. Upaya pengaplikasian langkah mitigasi dapat dilihat pada Gambar 2.

Gambar 2.

Suasana pemeriksaan kesehatan rutin pekerja proyek dan kondisi mess pekerja proyek
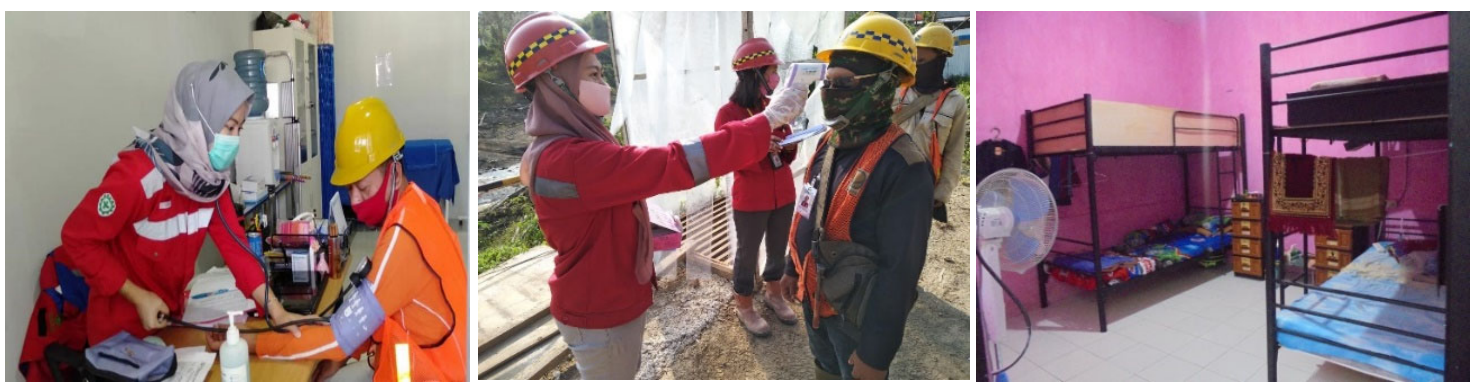

\section{Pelanggaran jaga jarak di ruang tunggu sopir dan ojek sesuai ketentuan} pencegahan penyebaran virus Covid-19.

Keterbatasan kapasitas ruang tunggu bagi sopir dan tukang ojek online berpotensi meningkatkan risiko penularan virus Covid-19 karena profesi tersebut mengharuskan mereka berada di ruang publik dan melakukan interaksi dengan banyak orang. Langkah mitigasi yang diambil adalah dengan menerapkan antrian sesuai dengan jumlah kapasitas ruang tunggu untuk sopir dan tukang ojek online yaitu apabila ruang tunggu sedang penuh maka dilakukan waiting list untuk dapat memasuki ruang tunggu. Pencegahan ojek online untuk memasuki ruang tunggu ketika kapasitas ruang tunggu sudah penuh juga diikuti oleh penerapan protokol prosedur pelaksanaan New Normal lainnya yaitu pengecekan suhu tubuh, memastikan penggunaan masker dan mencuci tangan dengan sabun. Prosedur penerapan langkah mitigasi tersebut dapat dilihat pada Gambar 3.

\section{Gambar 3.}

Prosedur penerimaan tamu, ruang tunggu dan ojek online siap memasuki ruang tunggu
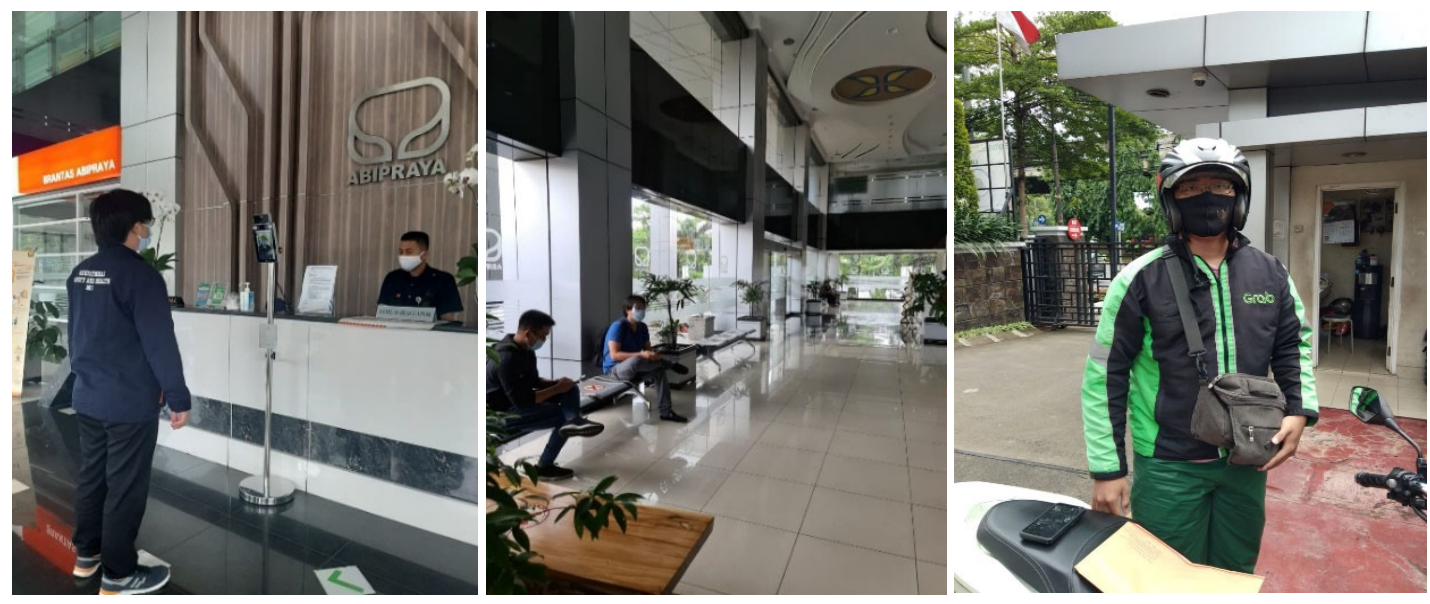


\section{Pelanggaran jaga jarak di ruang tunggu tamu/customer/oby sesuai ketentuan pencegahan penyebaran virus Covid-19.}

Tamu yang datang ke kantor pusat Abipraya diantaranya pihak eksternal perusahaan yang tidak tahu prosedur pelaksanaan New Normal, misalnya adanya peraturan jaga jarak di ruang tunggu untuk tamu atau di lobby perusahaan. Langkah mitigasi yang dilakukan adalah penerapan nomor antrian atau reservasi untuk dapat melakukan kunjungan ke kantor pusat Abipraya. Reservasi dilakukan dengan membuat janji terlebih dahulu dengan siapa yang akan ditemui atau melakukan pemberitahuan kepada receptionist tentang jadwal kunjungan yang akan dilakukan. Contoh penerapan reservasi kunjungan dapat dilihat pada Gambar 3. Kebijakan harus melakukan reservasi terlebih dahulu bisa mengontrol jumlah kunjungan di Abipraya. Jumlah kunjungan dapat dibatasi sehingga protokol jaga jarak dapat dilakukan. Abripraya pun menerapakn kebijakan pengurangan kapasitas ruang tunggu atau lobby sebanyak 50\% sehingga dapat menurunkan nilai risiko penularan virus Covid-19.

\section{Pelanggaran jaga jarak saat naik lift sesuai ketentuan pencegahan penyebaran virus Covid-19.}

Kondisi ruangan di dalam lift yang sempit dan terbatas membuat aktivitas menaiki lantai di kantor pusat Abipraya menjadi suatu aktivitas yang memiliki nilai risiko tinggi dalam kasus potensi penyebaran virus Covid-19. Langkah mitigasi yang dipilih untuk menurunkan nilai risiko untuk risiko penularan virus Covid-19 saat melakukan aktivitas menaiki lift adalah memberikan sticker berupa instruksi saat antri menunggu lift dan posisi serta kapasitas saat berada di dalam lift. Implementasi dari langkah mitigasi tersebut dapat dilihat pada Gambar 4. Dari Gambar telihat bagaimana implementasi langkah mitigasi yang diambil dan bagaimana penerapannya. Selain itu juga dilakukan sosialisasi tentang peraturan terkait agar para karyawan dapat menyesuaikan waktunya karena keterbatasan kapasitas penggunaan lift.

\section{Gambar 4.}

Implementasi pemasangan sticker penggunaan lift dan aplikasi mobile ayo sehat
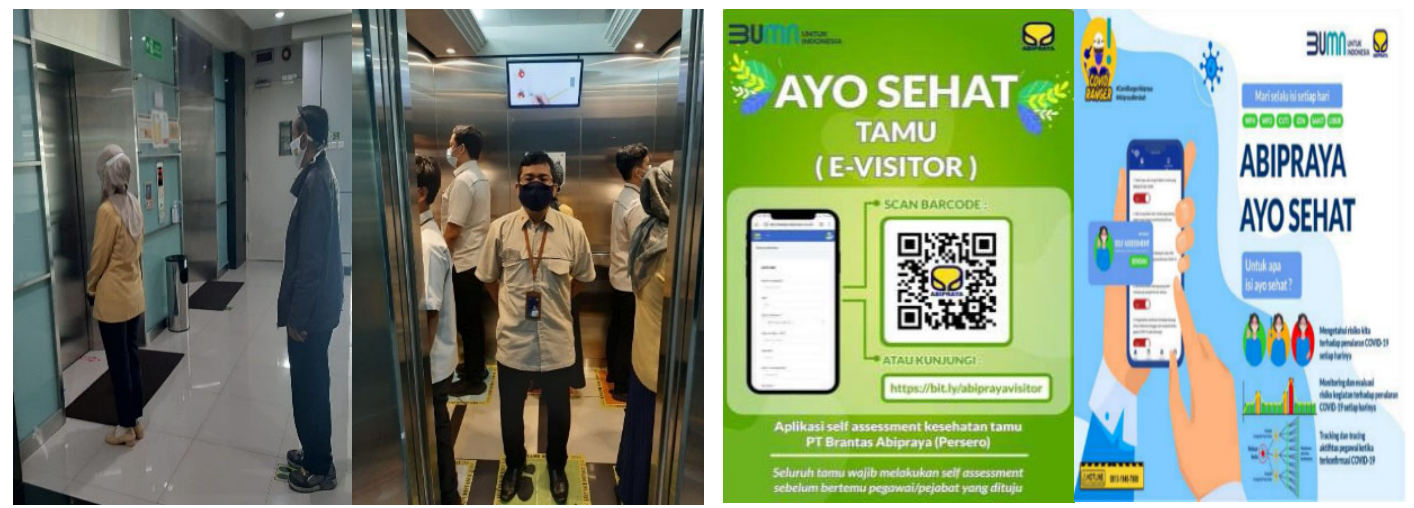


\section{Tidak semua tamu memiliki surat keterangan bebas Covid-19 terutama tamu dari dalam kota.}

Di tingkat pemerintahan, salah satu bentuk pencegahan penyebaran virus Covid-19, keberadaan surat keterangan bebas Covid-19 melalui hasil tes dari rapid test atau swab test atau PCR digunakan sebagai syarat untuk kunjungan ke luar daerah. Di tingkat perusahaan, Abipraya memiliki sebuah aplikasi mobile bernama "Ayo Sehat" yang berisi self assessment tentang riwayat bepergian seseorang dan gejala-gejala awal indikasi penularan virus Covid-19. Untuk menurunkan risiko penyebaran virus Covid-19 di lingkungan Abipraya yang disebabkan oleh tamu, Abripraya menggunakan aplikasi tersebut sebagai salah satu persyaratan kunjungan sebagai pengganti surat keterangan bebas Covid-19. Selama ini, aplikasi hanya digunakan untuk kepentingan internal Abipraya apabila karyawan selesai melakukan perjalanan dinas. Contoh user interface aplikasi "Ayo Sehat" Abipraya dapat dilihat pada Gambar 4.

\section{KESIMPULAN DAN SARAN}

\section{Kesimpulan}

Manajemen perusahaan telah melaksanakan mekanisme Business Continuity Management (BCM) sesuai dokumen manual dan SOP perusahaan. Di lain sisi, terdapat pelanggaran dan ketidaksesuaian yang bernilai skor risiko tinggi dengan alasan tidak tahu yang dilakukan oleh pihak eksternal, baik oleh pekerja proyek dan tamu perusahaan. Nilai risiko ini berpotensi bisa mengancam jalannya operasional perusahaan. Mengacu pada ISO 22301 daril 8 identifikasi risiko yag dinilai terdapat 6 risiko yang mempunyai level risiko very high, 1 risiko dengan level high, dan 1 risiko dengan level medium. Implikasi manajerial yang perlu dilakukan meningkatkan komitmen manajemen terhadap penerapan BCM melalui sosialisasi dan pelaksanaan rencana mitigasi secara berkala untuk menurunkan 6 risiko yang mempunyai level very high. Dukungan disiplin menjalankan BCM dari pihak eksternal seperti para vendor dan sub kontraktor.

\section{Saran}

Penelitian ini menyarankan beberapa rekomendasi yang dapat digunakan untuk penelitian lebih lanjut, yaitu melakukan assessment berdasarkan ISO 22317 untuk mengetahui sejauh mana dampak identifikasi risiko yang ada dapat berdampak bagi proses bisnis perusahaan, melakukan perhitungan analisis biaya yang dikeluarkan untuk melakukan langkah mitigasi terhadap besarnya penurunan nilai risiko sehingga dapat memilih langkah mitigasi yang efektif dengan tetap memperhatikan besarnya biaya yang dikeluarkan, melakukan perhitungan tingkat keefektivan penerapan mitigasi dalam kurun waktu tertentu. 


\section{REFERENSI}

Abipraya. (2020). Brantas abipraya siap laksanakan new normal. Retrieved from http://www.brantas-abipraya.co.id/id/berita/index/brantas-abipraya-siaplaksanakan-new-normal

Amanda, A. A. (2014). Business continuity plan pada teknologi dan sistem informasi BPR bank surya yudha Banjarnegara. (Skripsi), Institut Teknologi Sepuluh Nopember, Surabaya.

Baba, H. (2014). Area Business Continuity Management, a new opportunity for building economic resilience. Paper presented at the 4th International Conference on Building Resilience, Salford Quays.

Burtles, J. (2016). Principles and practice of business continuity: Tools and techniques. Brookfield: Rothstein Publishing.

de Castro Alves, D., \& de Almeida, M. M. G. (2015). Business continuity management (BCM) applied to transpetro's national operational control center. Procedia Computer Science, 55, 431-440. doi:10.1016/j.procs.2015.07.099

Harmoko, D. W. (2014). Perancangan bussines continuity plan (BCP) terhadap layanan teknologi informasi: Studi kasus instansi ALT, fakultas teknologi informasi. (Tesis), Universitas Indonesia, Depok.

Hikmah, N., \& Sukwika, T. (2021). Analisis hazard vulnerability terhadap mitigasi bencana di rumah sakit Jakarta medical center. Teknika: Jurnal Sains dan Teknologi, 17(1), 1-17. doi:10.36055/tjst.v17i1.9406

Kartikasari, S. E., \& Sukwika, T. (2021). Disiplin K3 melalui pemakaian alat pelindung diri (APD) di laboratorium kimia PT Sucofindo. VISIKES: Jurnal Kesehatan Masyarakat, 20(1), 41-50.

Prakasita, E. H., \& Ginardi, R. H. (2018). Tinjauhan kesiapan terhadap implementasi business continuity management systems berbasis ISO 22301 dan ISO 27001 (Studi Kasus : PT. JPK). Jurnal Ilmiah Ilmu Komputer, 13(2), 76-83. doi:10.30872/jim.v13i2.902

Putri, S. L. (2016). perancangan business continuity plan untuk teknologi informasi pada studi kasus STIE perbanas, jurusan sistem informasi. (Skripsi), Institut Teknologi Sepuluh Nopember, Surabaya.

Ramli, S. (2020). Manajemen bencana dan kelangsungan bisnis. Bekasi: Prosafe.

Sari, M. L., \& Sukwika, T. (2020). Sistem proteksi aktif dan sarana penyelamatan jiwa dari kebakaran di RSUD kabupaten Bekasi. Jurnal Ilmu Kesehatan Bhakti Husada: Health Science Journal, 11(2), 190-203. doi:10.34305/jikbh.v11i2.184

Setiawan, I., Waluyo, R., \& Pambudi, W. A. (2019). Perancangan business continuity plan dan disaster recovery plan teknologi dan sistem informasi menggunakan ISO 22301. Jurnal Rekayasa Sistem dan Teknologi Informasi, 3(2), 148-155. doi:10.29207/resti.v3i2.911

Sugiyono. (2017). Metode penelitian kuantitatif, kualitatif, dan R\&D. Bandung: Alfabeta. 
Svata, V. (2013). System view of business continuity management. Journal of Systems Integration, 4(2), 19-35. doi:10.20470/jsi.v4i2.152

Verma, S., \& Gustafsson, A. (2020). Investigating the emerging COVID-19 research trends in the field of business and management: A bibliometric analysis approach. Journal of Business Research, 118, 253-261. doi:10.1016/j.jbusres.2020.06.057

Waatters, J. (2010). The business continuity management desk reference: Guide to business continuity planning, crisis management \& IT disaster recovery: Business Leverages Ltd.

Yuliana. (2020). Corona virus diseases (covid-19): Sebuah tinjauan literatur. Wellness And Healthy Magazine, 2(1), 187-192. doi:10.30604/well.95212020

Zainudin, \& Samopa, F. (2017). Kajian kesiapan implementasi bisnis continuity management system (BCMS) berbasis ISO 22301 (Studi kasus: PT. XYZ). Jurnal Informatika Mulawarman, 12(2), 82-87. doi:10.31227/osf.io/v6uph 